\title{
Dielectric response of sandstones of Rajasthan in the frequency range 200 MHz-20 GHz
}

\author{
K. Dhoot ${ }^{1}$, Mukesh Vyas ${ }^{2 *}$, D.H. Gadani ${ }^{3}$ and Tanmay Pandit ${ }^{4}$ \\ ${ }^{1,2}$ Department of Physics, science faculty, Jai Nraian Vyas University Jodhpur -342001, Rajasthan, India \\ ${ }^{3,4}$ Department of Physics, School of Sciences Gujarat University, Ahmedabad-380 009, Gujarat, India \\ *Corresponding Author: Dr.kashyap.dhoot@gmail.com Tel.: +91-9351571145
}

Available online at: www.isroset.org

Received: 04/Feb/2019, Accepted: 14/Apr/2019, Online: 30/Apr/2019

\begin{abstract}
Dielectric response $\left(\varepsilon^{\prime}, \varepsilon^{\prime \prime}\right)$ of nine different dry and water saturated sandstone samples of Rajasthan were measured in the frequency range $200 \mathrm{MHz}-20 \mathrm{GHz}$. Result has been presented in the form of variation with frequency which showed characteristics features. The change observed in dielectric characteristic with water saturated sample is interpreted as existence of water molecules in free space of sandstones samples. The mechanisms that influence the dielectric values of sandstone are strongly dependent on the frequency of electromagnetic field. The ac conductivity, bulk density and porosity were also measured for dry and water saturated sandstone samples.
\end{abstract}

Keywords: dielectric constant, ac conductivity, sandstone, frequency, water saturated

\section{INTRODUCTION}

Dielectric behaviour of sandstone and rock samples are important in the field of mining, planning ground penetrating radar (GPR) [1-3], microwave remote sensing [4-12], calibration of time domain reflectrometer (TDR) [13-15], investigation of individual contribution, induced polarization and detection in pollutants in ground water. Several studies [16-25] have been reported in the literature on the dielectric properties of rocks. Their measurements are either at $\mathrm{MHz}$ or lower frequency or at one or very few microwave frequencies.

In this work we reported the variation in dielectric constant, ac conductivity and loss tangent for dry and wet sandstone samples in frequency range $200 \mathrm{MHz}-20 \mathrm{GHz}$ at room temperature $(300.15 \mathrm{~K})$. These parameter are related with water contain, chemical properties and physical properties like frequency, density, porosity, size of the sandstone particles, temperature and electrochemical interaction $[16,17,20,22]$. It is difficult to confirm the accurate contribution of each chemical and physical quantity to reported $\varepsilon$ 'and $\varepsilon^{\prime \prime}$ but in all parameter water saturation and frequency part are most dominate the dielectric response.

\section{EXPERIMENTAL}

(a) Sample collection and preparation

Nine sandstone samples were collected from open mining area of desert region of Rajasthan.

- $\quad$ Nagaur (Khatu Khurd $27.1563^{\circ} \mathrm{N}, 74.3499^{\circ} \mathrm{E}$ )

- Nagaur (badi khatu $27.1161^{\circ} \mathrm{N}, 74.3302^{\circ} \mathrm{E}$ )

- Nagaur (badi khatu $27.1161^{\circ} \mathrm{N}, 74.3302^{\circ} \mathrm{E}$ )

- Jodhpur ( Soorsagar $26.3098^{\circ} \mathrm{N}, 73.0048^{\circ} \mathrm{E}$ )

- Jodhpur ( Rohila Kalan $26.2303^{\circ} \mathrm{N}, 72.8604^{\circ} \mathrm{E}$ )

- Jodhpur ( Rohila Kalan $26.2303^{\circ} \mathrm{N}, 72.8604^{\circ} \mathrm{E}$ )

- Jodhpur( Balsamand $26.3357^{\circ} \mathrm{N}, 73.0329^{\circ} \mathrm{E}$ )

- Kota (Rawatbhata24.9306 $\left.{ }^{\circ} \mathrm{N}, 75.5909^{\circ} \mathrm{E}\right)$

- Jaisalmer( Jethwai $26.9805^{\circ} \mathrm{N}, 70.9190^{\circ} \mathrm{E}$ ) 
Each sample was cut by a diamond wheel cutter and was polished to get fine surface for proper probe contact. Three samples were prepared from a same piece of the original sandstone rock and are shown in figure 1. Samples were fully dried using oven for 7-8 hour at a temperature of $90^{\circ} \mathrm{c}$ for measurement and wet samples were saturated with distilled water for seven days. Before measurements water on surface of the sample was removed using soft tissue paper.
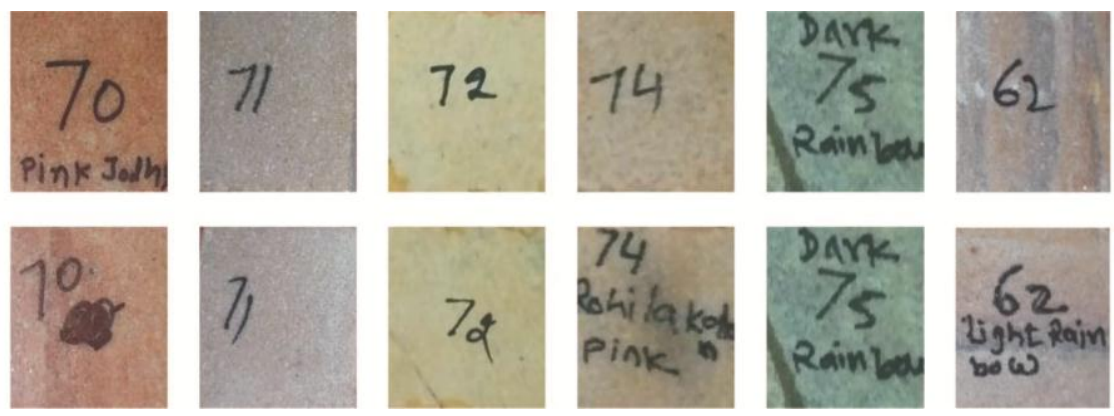

Figure: 1 - sandstone samples of Rajasthan
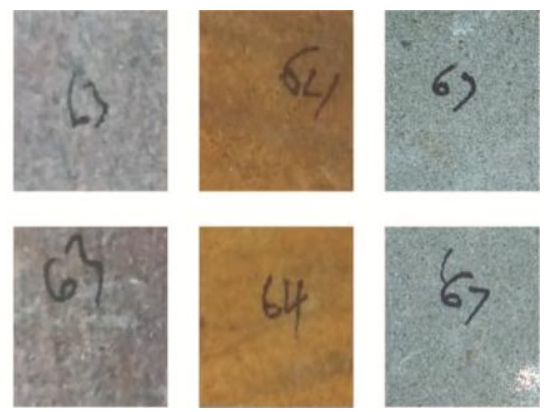

(a) Analysis of physical and chemical properties

The physical and chemical properties of the sandstone samples were measured at "Moni's Grosam Engineering Lab" Jodhpur. They are presented in table $1 \& 2$ respectively.

\section{(b) Measurement Method}

The measurement were carried out using Anritsu Shockline Vector Network Analyzer [26], (VNA) Model No.MS46322A along with SPEAG DAK dielectric assessment kit at Microwave Research Laboratory, Department of Physics, School of Sciences, Gujarat University, Ahmedabad, India. It is used to measure the dielectric parameters like dielectric constant, dielectric loss, loss tangent, etc. for dry and water saturated samples. For calibration we use two liquids HPLC water and Methanol to nullify the measurement error. Dry and wet samples are gently brought into contact with the probe tip. Sweep is commanded to Anritsu Shockline VNA through DAK software. Dielectric constant, dielectric loss, loss tangent and electrical conductivity have been carried out by this software.

\section{RESULTS AND DISCUSSION}

The variation in dielectric constant at different frequencies for dry and wet sandstone samples for Nagaur, Jodhpur, Kota and Jaisalmer region are shown in figure 2 - 4 respectively. The values of dielectric constant of dry sandstone samples of Nagaur region varies from 3.80 to 1.41 and for wet samples varies from 6.90 to 2.57. The values of dielectric constant of dry sandstone samples of Jodhpur region varies from 4.71 to 1.49 and for wet samples varies from 6.63 to 2.32 . The values of dielectric constant of dry sandstone samples of Kota region varies from 3.98 to 1.69 and for wet samples varies from 4.78 to 3.57.The values of dielectric constant of dry sandstone samples of Jaisalmer region varies from 7.32 to 4.19 and for wet samples varies from 7.95 to 6.25. From these graphs it is clear that the values of dielectric constant of sandstone samples for four district of Rajasthan are shown same variation.

The value of dielectric constant of dry sandstone sample of Jaisalmer is obtained higher (7.32) at frequency $200 \mathrm{MHz}$ while for Jodhpur sample dielectric constant value is lower (2.41) at frequency $200 \mathrm{MHz}$. The value of dielectric constant wet sandstone sample of Jaisalmer is obtained higher (7.95) at frequency $200 \mathrm{MHz}$ while for Jodhpur sample dielectric constant value is lower (4.58) at frequency $200 \mathrm{MHz}$. In general the value of dielectric constant for dry sandstone samples of all district decreases with increase in frequency from $200 \mathrm{MHz}$ to $10000 \mathrm{MHz}$ after that its values slightly increases and remains almost constant. The same variation in dielectric constant of all wet samples of four districts is obtained only the difference is that the value of dielectric constant is greater than the dry sample.

The variation in ac conductivity at different frequencies for dry and wet sandstone samples of Nagaur, Jodhpur, Kota and Jaisalmer region are shown in figure 5 to 7 respectively. The values of ac conductivity of dry sandstone samples of Nagaur region varies from 0.141 to 0.009 and for wet samples varies from 1.231 to 0.038 . The values of ac conductivity of dry sandstone samples of Jodhpur region varies from 0.177 to 0.004 and for wet samples varies from 1.167 to 0.038 .The values of ac conductivity of dry sandstone samples of Kota region varies from 0.208 to 0.010 and for wet samples varies from 0.609 to 
0.040.The values of ac conductivity of dry sandstone samples of Jaisalmer region varies from 0.469 to 0.014 and for wet samples varies from 1.003 to 0.043 .

The value of ac conductivity dry sandstone sample of Jaisalmer is obtained higher (0.469) at frequency $20000 \mathrm{MHz}$ while for Nagaur sample ac conductivity value is lower $(0.126)$ at frequency $20000 \mathrm{MHz}$. The value of ac conductivity wet sandstone sample of Nagaur is obtained higher (1.231) at frequency $20000 \mathrm{MHz}$ while for Jodhpur sample ac conductivity value is lower (0.366) at frequency $20000 \mathrm{MHz}$

The value of ac conductivity for dry sandstone sample of Nagaur increases with frequency up to $4000 \mathrm{MHz}$ after that it decreases up to $9000 \mathrm{MHz}$ and then it increases continuously up to $20000 \mathrm{MHz}$. The value of ac conductivity for dry sandstone sample of Jodhpur increases with frequency up to $5000 \mathrm{MHz}$ after that it decreases up to $10000 \mathrm{MHz}$ and then it increases continuously up to $20000 \mathrm{MHz}$ and the value of ac conductivity for dry sandstone sample of Kota and Jaisalmer increases with frequency up to $4000 \mathrm{MHz}$ after that it decreases up to $11000 \mathrm{MHz}$ and then it show irregular variation in ac conductivity but for all wet sandstone sample of four district it increases continuously with frequency. The increase in ac conductivity is more at higher frequency region.

The variation in loss tangent with frequency for dry and wet sandstone samples of for Nagaur, Jodhpur, Kota and Jaisalmer region are shown in figure 8 to 10 respectively. The values of loss tangent of dry sandstone samples of Nagaur region varies from 0.294 to 0.010 and for wet samples varies from 0.749 to 0.090 . The values of loss tangent of dry sandstone samples of Jodhpur region varies from 0.260 to 0.001 and for wet samples varies from 0.762 to 0.047 .The values of loss tangent of dry sandstone samples of Kota region varies from 0.232 to 0.030 and for wet samples varies from 0.756 to 0.083 .The values of loss tangent of dry sandstone samples of Jaisalmer region varies from 0.175 to 0.001 and for wet samples varies from 0.486 to 0.074 .

The trend of loss tangent for dry sandstone sample of four district shows zig-zag variation with increase in frequency while for wet sample it decreases with increase in frequency from $200 \mathrm{MHz}$ to $5000 \mathrm{MHz}$ after that its value increases with

The variation in dielectric constant of dry rock and mineral samples at microwave frequencies is mainly due to variation in sample density and also due to the change in chemical composition of sample. The real part of dielectric permittivity dry geological sample remains almost frequency independent in the microwave region. The value of dielectric constant of Nagaur and Jodhpur region are same \& also related with their density. The computed average values of density reduced permittivity $\left(\varepsilon^{\prime}{ }_{\mathrm{dr}}\right)=\left(\varepsilon^{\prime}\right)^{1 / \mathrm{d}}$ of Nagaur and Jodhpur sandstone sample were found 1.28 and 1.39 . The values of density reduced permittivity of Jaisalmer sandstone is higher than the other sandstone sample $\left(\varepsilon^{\prime}{ }_{\mathrm{dr}}=1.74\right)$. Some sandstone sample show the enhancement in dielectric constant is proportional to water absorption in the sample and hence dielectric constant is proportional to porosity. The irregular variation in $\varepsilon^{\prime \prime}$ values is observed with increase in sample porosity. There is no directed convincing correlation between $\varepsilon^{\prime \prime}$ values and bulk density of dry sandstone sample. The increase in percentage of $\mathrm{Fe}_{2} \mathrm{O}_{3}$ and $\mathrm{Al}_{2} \mathrm{O}_{3}\left(\varepsilon^{\prime}>12\right)$ in chemical composition of sandstone sample increases the $\varepsilon^{\prime}$ values at frequency $200 \mathrm{MHz}$. The value $\varepsilon^{\prime}$ of Jaisalmer sandstone sample is higher in comparison to other sandstone sample.

\section{IV.CONCLUSION}

The variation in dielectric constant of dry sandstone samples of Nagaur, Kota, Jaisalmer and Jodhpur, shows same pattern but different values of dielectric constant with frequency. This indicates that apart from water content in the sandstone samples, chemical composition physical properties and its grain geometries also affect the dielectric constant ( $\left.\varepsilon^{\prime}\right)$ of the sandstone sample.

At low frequency dielectric constant of dry samples higher and it decreases with increase in frequency i.e. dry rock and mineral material show dielectric dispersion in low frequency region. In geological materials the low frequency dispersion is believed due to polarization associated with charge build up at grain boundaries or grain imperfection. At high frequency region it shows almost constant trend i.e. in microwave region the value of dielectric constant of dry rock and mineral samples are almost independent of the frequency. Similar response was found for wet samples with higher values of dielectric constant. At low frequency region ac conductivity of wet sample is small and constant but at microwave region ac conductivity is abruptly rises. 
Table 1: Physical Properties of Sandstone samples of different region of Rajasthan

\begin{tabular}{|c|c|c|c|c|c|}
\hline S. No. & Location (Region) & Color & WA $(\%)$ & Porosity (\%) & Density $(\mathrm{gm} / \mathrm{cc})$ \\
\hline 62 & $\begin{array}{l}\text { Nagaur (badi khatu } \\
27.1161^{\circ} \mathrm{N}, 74.3302^{\circ} \mathrm{E} \text { ) }\end{array}$ & Light Rainbow & 3.16 & 7.33 & 2.85 \\
\hline 64 & $\begin{array}{l}\text { Nagaur (badi khatu } \\
\left.27.1161^{\circ} \mathrm{N}, 74.3302^{\circ} \mathrm{E}\right)\end{array}$ & Teakwood (yellow) & 7.16 & 14.13 & 1.91 \\
\hline 75 & $\begin{array}{l}\text { Nagaur (Khatu Khurd } \\
\left.27.1563^{\circ} \mathrm{N}, 74.3499^{\circ} \mathrm{E}\right)\end{array}$ & Dark Rainbow & 3.58 & 7.74 & 2.20 \\
\hline 70 & $\begin{array}{l}\text { Jodhpur (Soorsagar } \\
\left.26.3098^{\circ} \mathrm{N}, 73.0048^{\circ} \mathrm{E}\right)\end{array}$ & Pink & 3.47 & 8.08 & 2.42 \\
\hline 71 & $\begin{array}{l}\text { Jodhpur (Rohila Kalan } \\
\left.26.2303^{\circ} \mathrm{N}, 72.8604^{\circ} \mathrm{E}\right)\end{array}$ & Beige Pink & 2.63 & 5.92 & 2.31 \\
\hline 74 & $\begin{array}{l}\text { Jodhpur (Rohila Kalan } \\
\left.26.2303^{\circ} \mathrm{N}, 72.8604^{\circ} \mathrm{E}\right)\end{array}$ & Pink & 3.16 & 7.33 & 2.35 \\
\hline 63 & $\begin{array}{l}\text { Jodhpur (Balsamand } \\
\left.26.3357^{\circ} \mathrm{N}, 73.0329^{\circ} \mathrm{E}\right)\end{array}$ & Red & 2.34 & 5.72 & 2.60 \\
\hline 67 & $\begin{array}{l}\text { Kota (Rawatbhata } \\
\left.24.9306^{\circ} \mathrm{N}, 75.5909^{\circ} \mathrm{E}\right)\end{array}$ & Grey & 2.93 & 7.01 & 2.47 \\
\hline 72 & $\begin{array}{l}\text { Jaisalmer (Jethwai } \\
\left.26.9805^{\circ} \mathrm{N}, 70.9190^{\circ} \mathrm{E}\right)\end{array}$ & Yellow & 3.32 & 8.15 & 2.60 \\
\hline
\end{tabular}

Table 2: Chemical Properties of Sandstone samples of different region of Rajasthan

\begin{tabular}{|c|c|c|c|c|c|c|c|c|}
\hline S.No. & Location (Region) & $\mathrm{CaCo}_{3}$ & $\mathrm{MgCo}_{3}$ & $\mathrm{SiO}_{2}$ & LOI & $\mathrm{Fe}_{2} \mathrm{O}_{3}$ & $\mathrm{Al}_{2} \mathrm{O}_{3}$ & $\mathrm{Mno}_{2}$ \\
\hline 62 & $\begin{array}{l}\text { Nagaur (badi khatu } \\
27.1161^{\circ} \mathrm{N}, 74.3302^{\circ} \mathrm{E} \text { ) }\end{array}$ & 1.4 & 3.84 & 86.01 & 1.85 & 1.67 & 1.18 & 1.1 \\
\hline 64 & $\begin{array}{l}\text { Nagaur (badi khatu } \\
\left.27.1161^{\circ} \mathrm{N}, 74.3302^{\circ} \mathrm{E}\right)\end{array}$ & 1.18 & 6.32 & 83.18 & 2.89 & 1.07 & 1.41 & 0.1 \\
\hline 75 & $\begin{array}{l}\text { Nagaur (Khatu Khurd } \\
\left.27.1563^{\circ} \mathrm{N}, 74.3499^{\circ} \mathrm{E}\right)\end{array}$ & 5.14 & 4.98 & 80.04 & 1.44 & 1.14 & 0.63 & - \\
\hline 70 & $\begin{array}{l}\text { Jodhpur (Soorsagar } \\
\left.26.3098^{\circ} \mathrm{N}, 73.0048^{\circ} \mathrm{E}\right)\end{array}$ & 0.84 & 1.07 & 89.41 & 0.98 & 1.70 & 1.97 & 0.07 \\
\hline 71 & $\begin{array}{l}\text { Jodhpur (Rohila Kalan } \\
\left.26.2303^{\circ} \mathrm{N}, 72.8604^{\circ} \mathrm{E}\right)\end{array}$ & 3.1 & 2.18 & 84.68 & 0.90 & 1.55 & 0.63 & 0.08 \\
\hline 74 & $\begin{array}{l}\text { Jodhpur (Rohila Kalan } \\
\left.26.2303^{\circ} \mathrm{N}, 72.8604^{\circ} \mathrm{E}\right)\end{array}$ & 1.44 & 1.78 & 88.72 & 1.60 & 1.68 & 1.07 & - \\
\hline 63 & $\begin{array}{l}\text { Jodhpur (Balsamand } \\
\left.26.3357^{\circ} \mathrm{N}, 73.0329^{\circ} \mathrm{E}\right)\end{array}$ & 1.47 & 2.84 & 87.08 & 1.05 & 1.94 & 1.80 & - \\
\hline 67 & $\begin{array}{l}\text { Kota (Rawatbhata } \\
\left.24.9306^{\circ} \mathrm{N}, 75.5909^{\circ} \mathrm{E}\right)\end{array}$ & 1.32 & 4.32 & 85.60 & 1.84 & 1.79 & 1.60 & 4.32 \\
\hline 72 & $\begin{array}{l}\text { Jaisalmer (Jethwai } \\
\left.26.9805^{\circ} \mathrm{N}, 70.9190^{\circ} \mathrm{E}\right)\end{array}$ & 4.18 & 3.68 & 76.71 & 1.4 & 4.1 & 1.68 & - \\
\hline
\end{tabular}




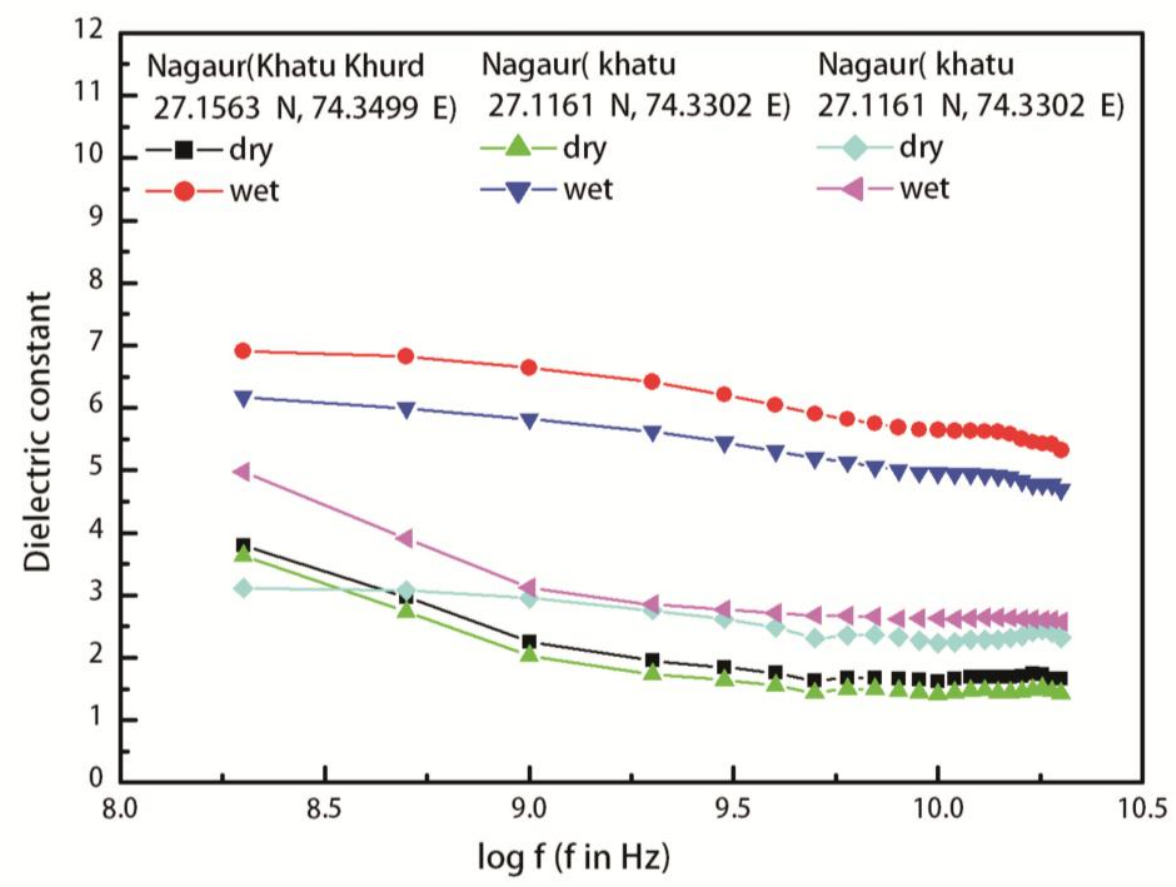

Figure:-2 Dielectric constant with frequency for dry and wet sandstone samples of Nagaur region

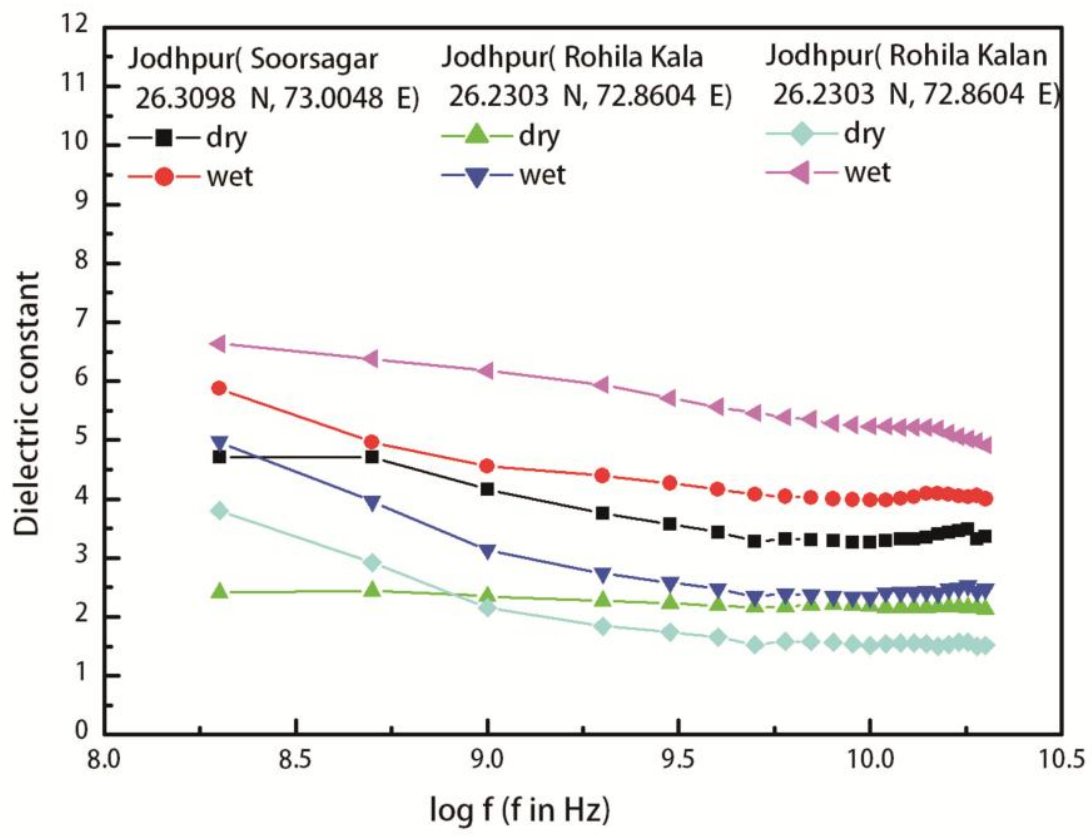

Figure:-3 Dielectric constant with frequency for dry and wet sandstone samples of Jodhpur region 


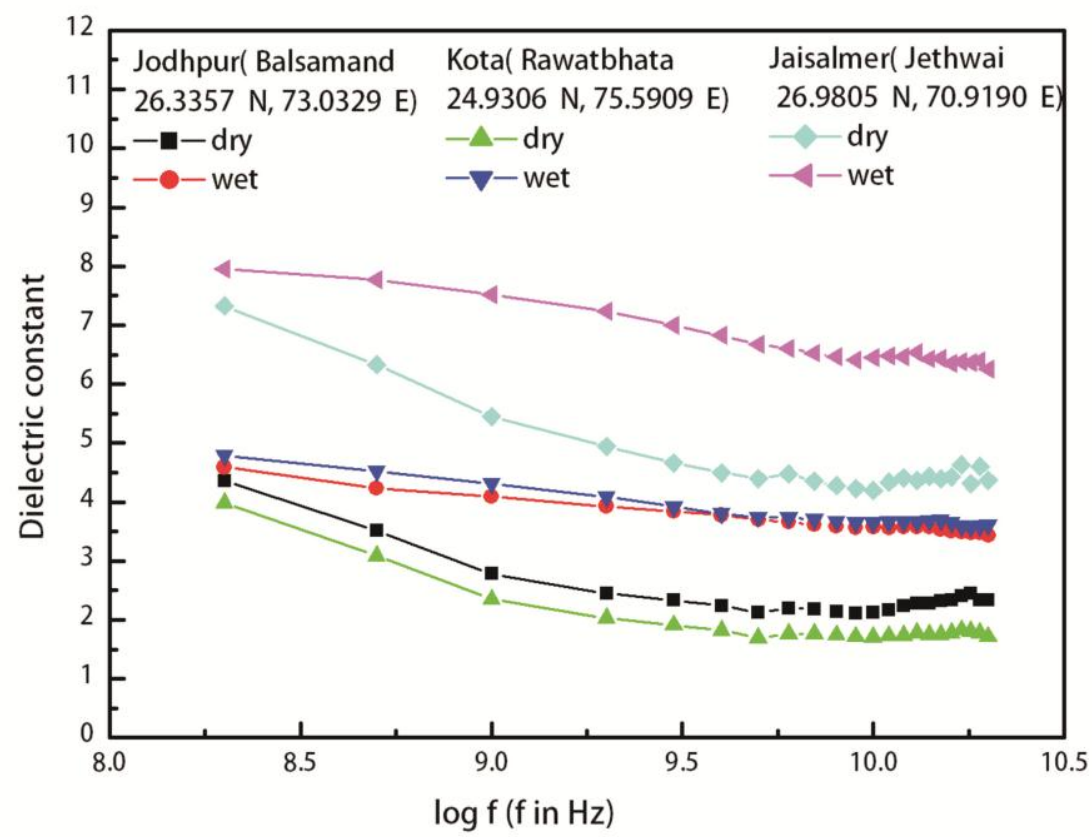

Figure:-4 Dielectric constant with frequency for dry and wet sandstone samples of Jodhpur, Kota and Jaisalmer region

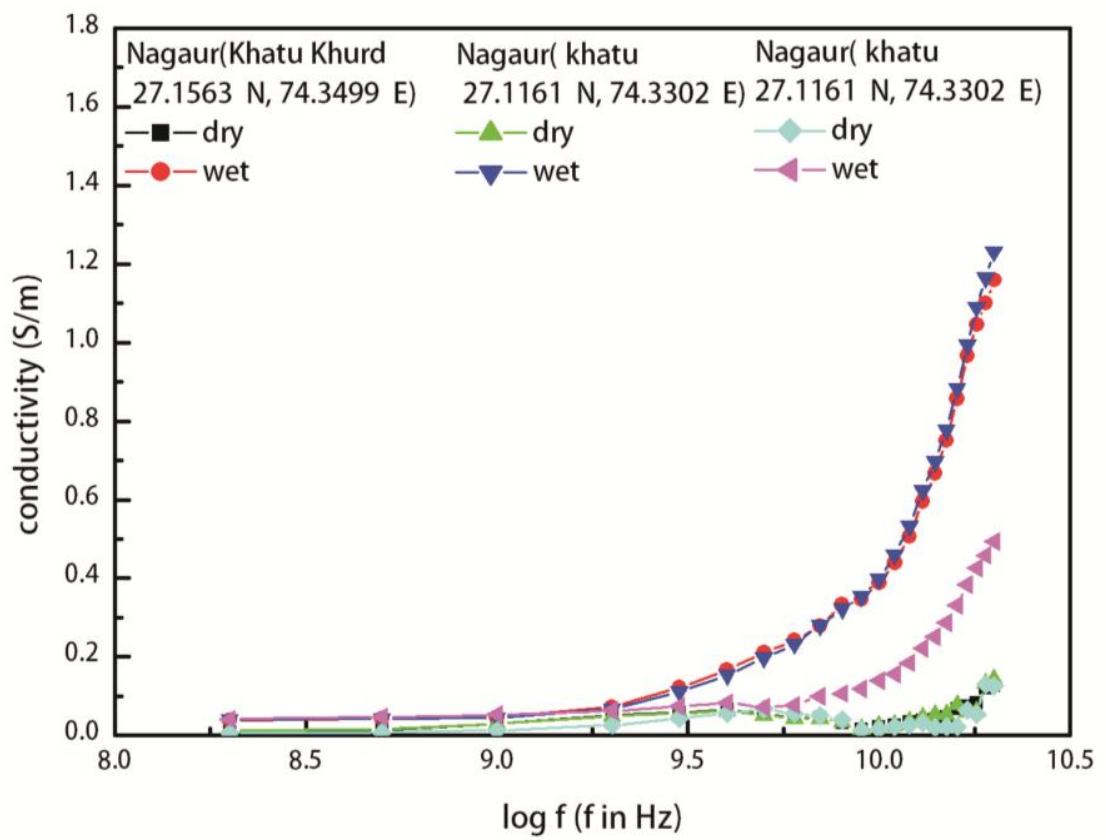

Figure: - 5 AC Conductivity with frequency for dry and wet sandstone samples of Nagaur region 


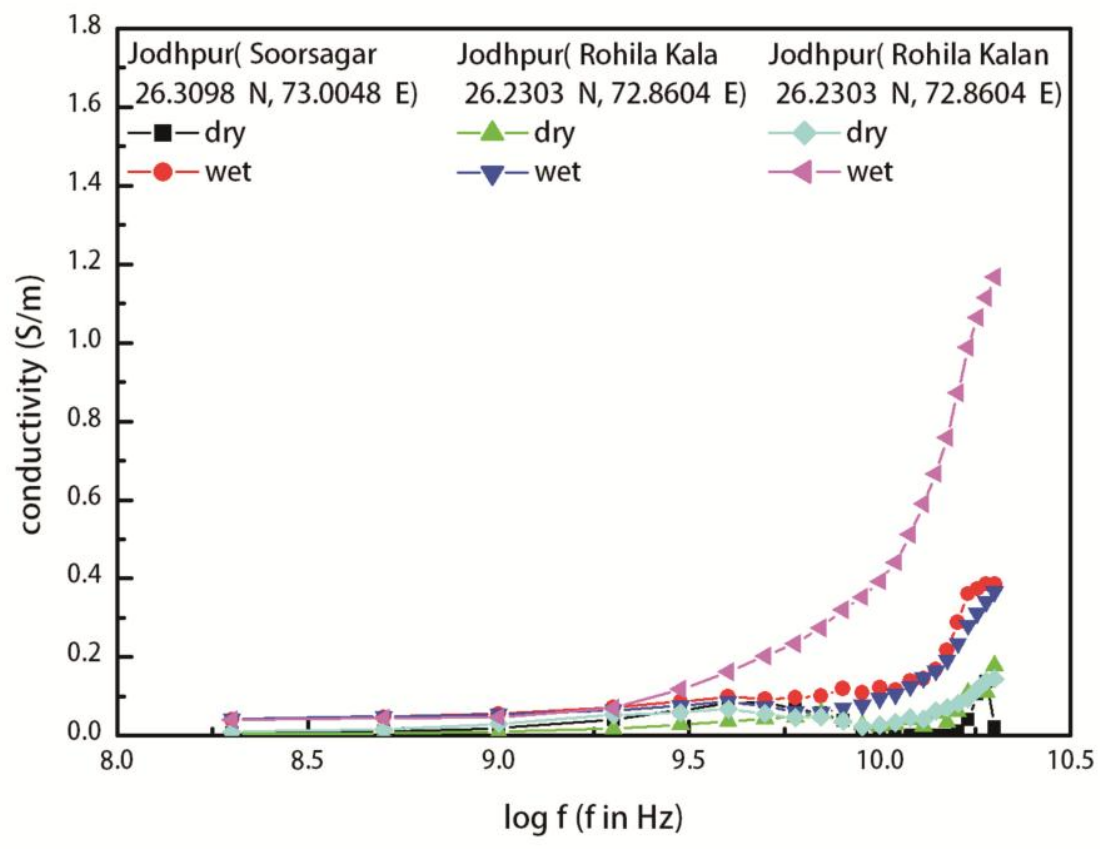

Figure: - 6 AC Conductivity with frequency for dry and wet sandstone samples of Jodhpur region

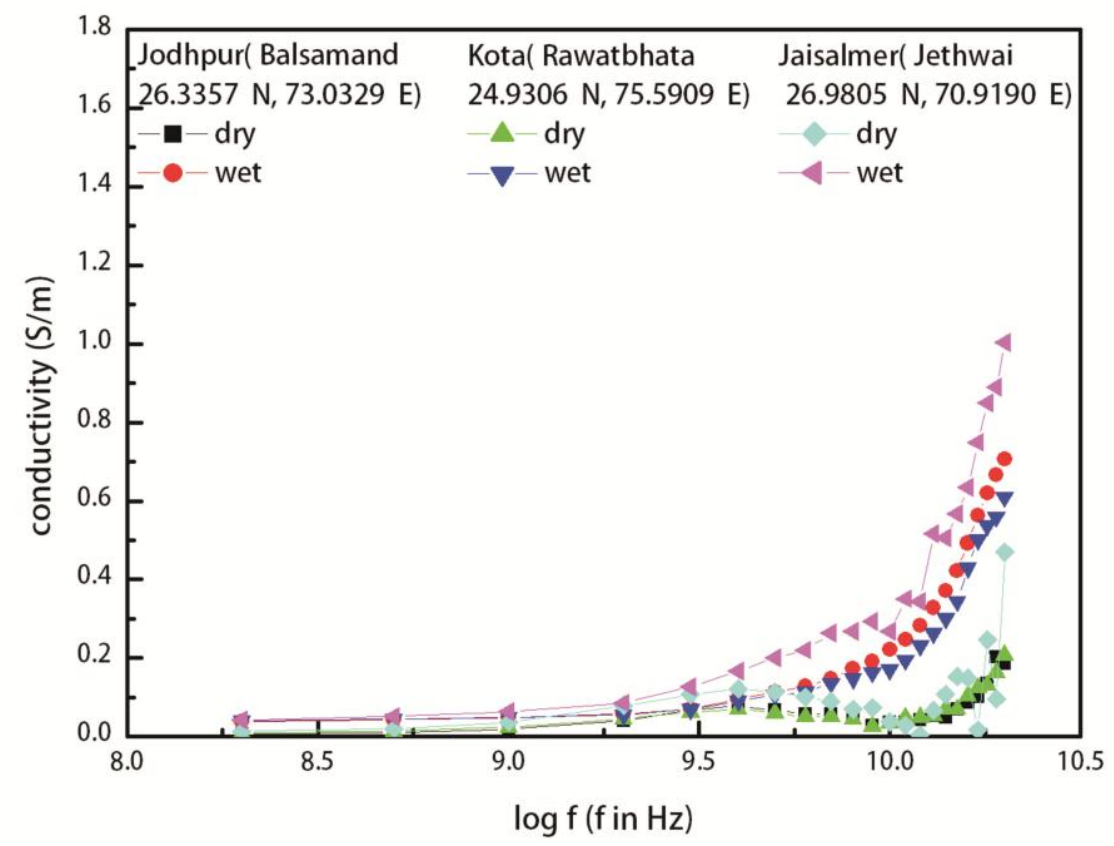

Figure:- 7 AC Conductivity with frequency for dry and wet sandstone samples of Jodhpur, Kota and Jaisalmer region 


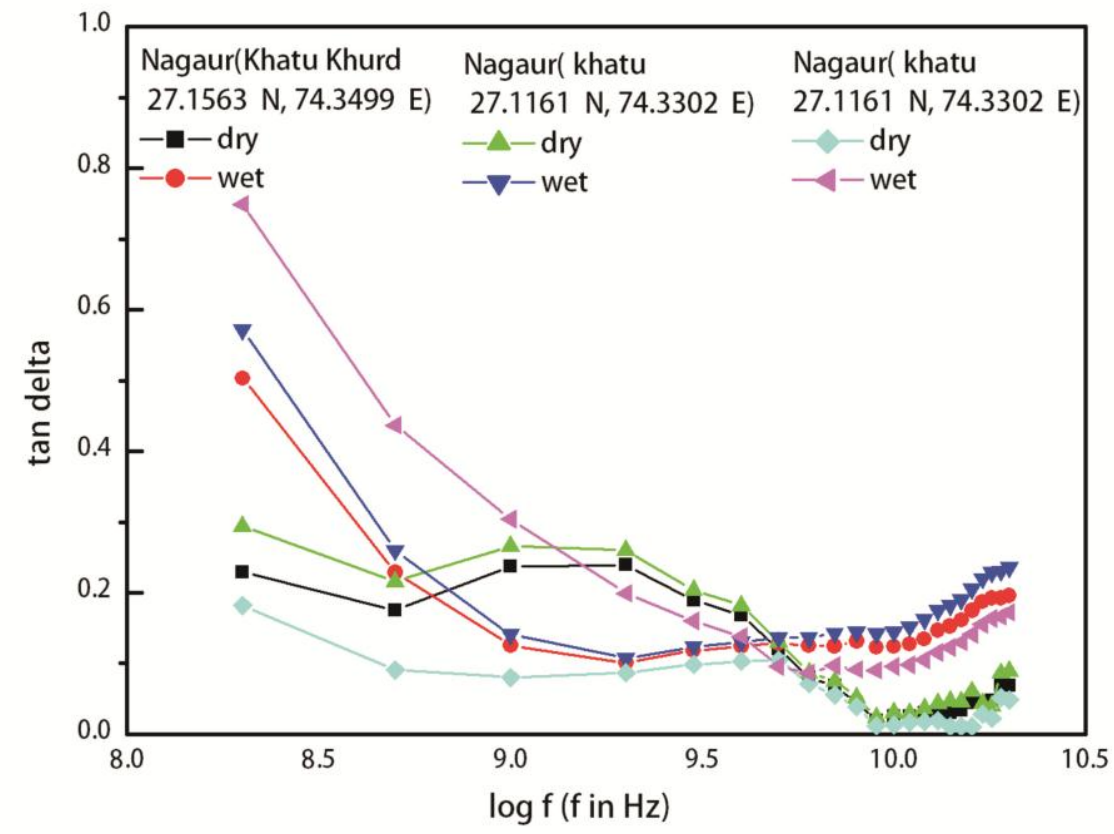

Figure: - 8 Loss Tangent with frequency for dry and wet sandstone samples of Nagaur region

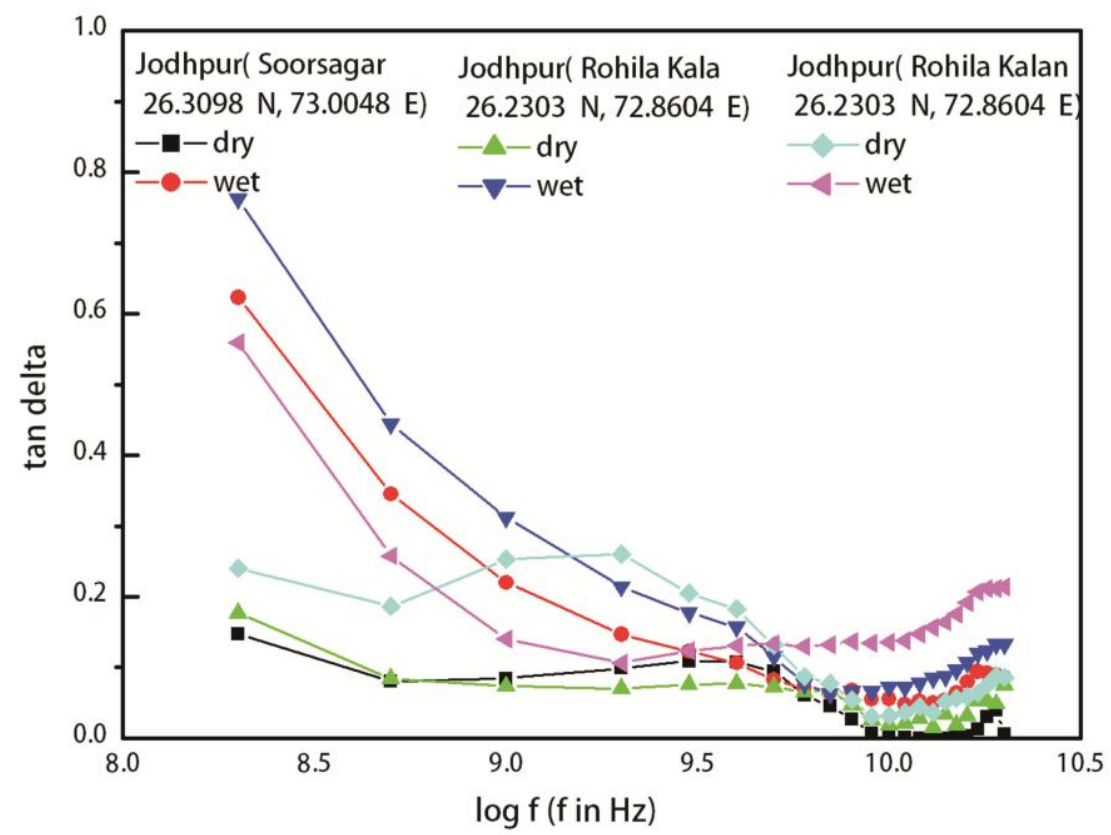

Figure: - 9 Loss Tangent with frequency for dry and wet sandstone samples of Jodhpur region 


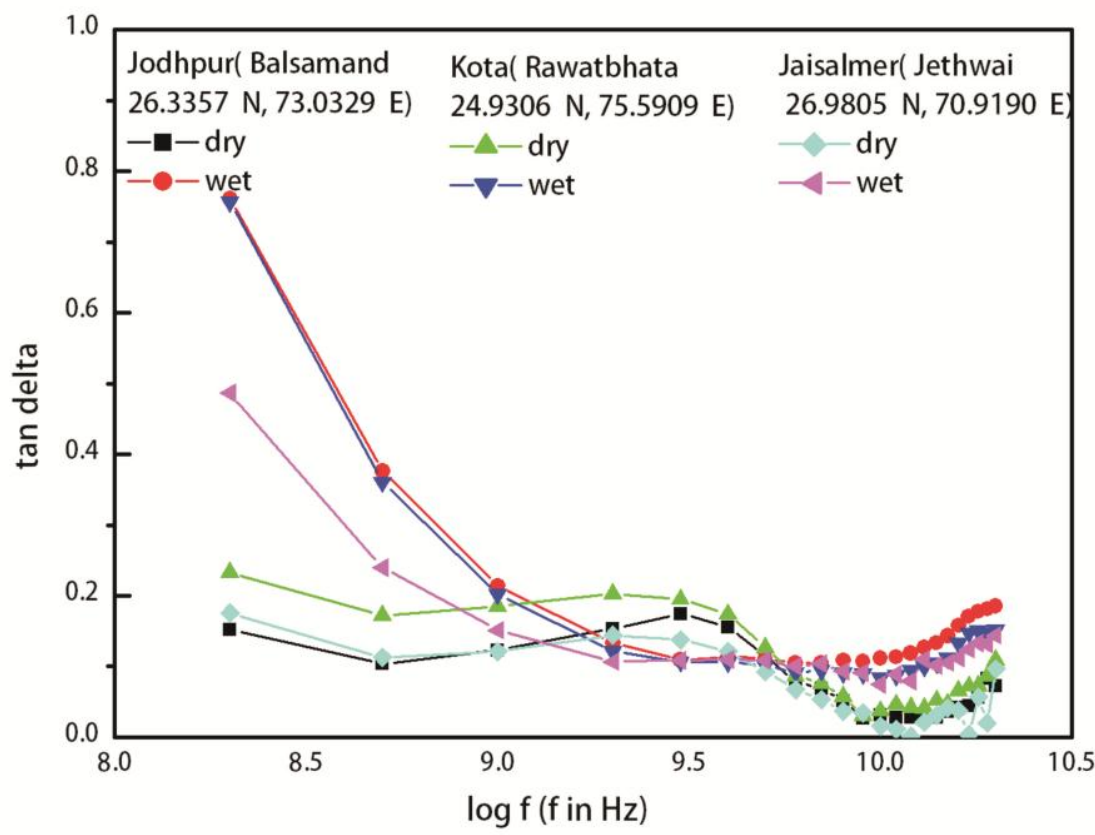

Figure: - 10 Loss Tangent with frequency for dry and wet sandstone samples of Jodhpur, Kota and Jaisalmer region

\section{ACKNOWLEDGMENT}

The authors are greatful to Prof (Dr.) P. N. Gajjar, Head Department of Physics, Gujarat University, Ahmedabad, for providing laboratory facilities under funding agency DST, New Delhi and UGC for providing financial assistant through DSTFST project (grant no. SR/FST/PSI-198/2014). Heartful thanks to Prof. (Dr.) A.D. Vyas, (Former Head) and Prof. Vipin A.Rana, Department of Physics, Gujarat University, Ahmedabad, for continuous mentorship. We are also thankful to Prof (Dr.) S.K. Sharma, (Head) and Prof. (Dr.) R. J. Sengwa, (Former Head) Department of Physics, Jai Narain Vyas University, Jodhpur for constant encouragement.

\section{REFERENCES}

[1] A. Robert, "Dielectric permittivity of concrete between $50 \mathrm{MHz}$ and $1 \mathrm{GHz}$ and GPR measurements for building materials evaluation", J. Appl. Geophys., Vol.40, pp. 89-94,1998.

[2] G. A. McMechan, R.G. Loucks, X. Zeng and P. Mescher, "Ground penetrating radar imaging of a collapsed paleocave system in the Ellenburger dolomite, central Texas", J. Appl. Geophys, Vol. 39,pp.1-10,1998.

[3] A. Martinez and A.P. Byrnes, “ Modeling dielectric-constant values of geologic materials: An aid to ground-penetrating radar data collection and interpretation”, Current Research in Earth Sciences, Kansas Geological Survey, Bulleting 247, part 1, pp. 1-16, 2001.

[4] F.T. Ulaby, T.H.Bengal, M.C.Dobson, J.R.East, J.B.Garvin and D.L. Evans, "Microwave dielectric properties of dry rocks ", IEEE Trans Geosci. Remote sensing Vol. 28, Issue.3, pp. 325-336, 1990.

[5] B. Cervelle and X .Jin-Kai . "Dielectric properties of minerals and rocks; Applications to microwave remote sensing," in A. S. Marfunin, ed, Advanced mineralogy 1: Springer -Verlage Berlin, 1994.

[6] D.J.Daniels,Surface -penetration radar: IEE Radar, Sonar, Navigation and Avionics series 6 : Institute of Electrical Engineers. 1996.

[7] Z.C. Alex and J. Behari, Indian J Pure \& Appl Phys, Vol. 34, pp. 319-332, 1996.

[8] A. Ghosh, J. Behari and S. Pyne, "Dielectric parameters of dry and wet soils at 14.89 GHz", Indian J Radio \& Space Phys, Vol. 27 pp. 130-134, 1998.

[9] O. P. N Calla, M. C. Bora, P.Vashishtha, R. Mishra, A. Bhattacharya and S. P. Purohit, "Study of the properties of dry and wet loamy sand soil at microwave frequencies", Indian J. of Radio and Space Physics, vol. 28 pp.109-112, 1999. 
[10] D.P. Lesmes and F.D. Morgan, “Dielectric spectroscopy of sedimentary rocks”, J. Geophys. Res., Vol.106, pp. 13329-13346, 2001.

[11] J. Behari, “Microwave Measurement Techniques and Applications”, Anamaya Publishers, New Delhi, 2003.

[12] O. P. N Calla, D. Bohra, S. k .Agarwalla, S. Gosh, C. Bohra, and R. Vyas, "Comparison of emissivity and scattering coefficient of two samples of Aravali rocks and dry soils of Rajasthan at frequencies of X-band", Indian J. Radio and Space Physics,Vol.36, pp.65-71,2007.

[13] A. A. Poinzovsky, S. M. Chudinova and Y.A. "Pachepksy, Performance of TDR calibration models as affected by cement paste" J. Hydrology, Vol. 218, pp.35-43, 1999.

[14] S.Kumar,R.Amalanathan, "Dielectric Relaxation Studies of Triethanolamine with 2-Alkoxyethanol using time Domain Reflectometry Technique, "International Journal of Scientific Research in Physics and Applied Sciences, Vol.7, Issue.1, pp.18-34, 2019,

[15] Daosheng Ling, Yun Zhao, Yunlong Wang, and Bo Huang, "Study on Relationship between Dielectric Constant and Water Content of RockSoil Mixture by Time Domain Reflectometry” Hindawi Publishing Corporation Journal of Sensors , pp. 1-10, 2016.

[16] R.J. Sengwa, A. Soni, B. Ram, "Dielectric behaviour of shale and calcareous sandstone of Jodhpur region", Indian J. Radio and Space Physics, Vol. 33, pp.329-335, 2004.

[17] R.J. Sengwa, A.Soni," Dielectric dispersion and microwave dielectric study of marble in support of radar investigations", Indian Journal of pure \& Applied Physics, Vol.43, pp. 777-782, 2005.

[18] R.J.Sengwa, S.Sankhla, A.Soni, and B.Ram, “Dielectric Characterization of Dry and Water-Saturated Sandstones", Proc Indian Natn Sci Acad. Vol.73 issue 3, pp.147-155, 2007.

[19] Josann L., RosnNnorz and Duornv T. Surrn, "The dielectric constant of mineral powders" The American Mineralogist, Vol. 83, pp.115-120, 1932.

[20] Singh R. and Singh K.P., "Microwave measurements on some Indian coal samples." Applied Physics section, Institute of Technology, Banaras Hindu University Vol. 45, pp. 397-405, 1979.

[21] Singh Rameh, Singh Mahendra P. and Tarksewar Lal,"Laboratory measurement of dielectric constant and loss tangent of Indian rock samples", Annals of Geophysics Vol. 33,pp.121-140, 1980.

[22] R. Singh, Ramesh P. Singh and K P Singh, "Study of microwave response of coal and sandstone samples", Indian Acad. Sci. (Earth Planet. Sei.), Vol. 89, pp. 249-2 59,1980

[23] B. Patil Chhaya and P.R. Chaudhari , "Dielectric Constant and Emissivity of Rock Samples at Microwave Frequencies", International Journal of Innovative Research in Science, Engineering and Technology Vol. 5, pp.16267-16272, 2016.

[24] C. A Dias, "Developments in model to describe low-frequency electric polarization of rocks", Geophysics, Vol. 65 issue 2, pp. 437-451, 2000.

[25] K.K. Kumar and L. Sirdeshmukh, “ Dielectric properties and electrical conductivity studies on some minerals”, Indian J. Pure Appl. Phys. Vol. 34, pp.559-565, 1996.

[26] K. Dhoot , M. Vyas , A. D. Vyas , V. A.Rana , D. H. Gadani and T. Pandit, "Dielectric study of dry and wet granite stones at microwave frequency." International Journal of Scientific Research and Reviews, Vol. 7 issue1 Suppl., 310-320,2018.

\section{AUTHORS PROFILE}

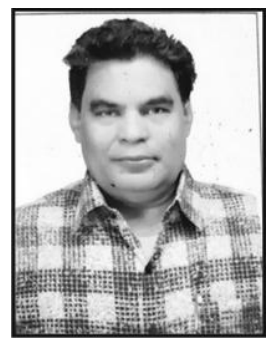

Dr. Kashyap Dhoot has completed his M.Sc (Physics), and Ph.D in 1985 and 1989 respectivelty. He is currently working as Assistant Professor in the Department of Physics, Jai Narain Vyas University, Jodhpur, Rajasthan . He has published more than 10 Papers in reputed national and international journals / conferences. His main research work focuses on Mossabuer Spectroscopy Corrosion Science. He has 25 years of teaching and research experience. 